\title{
Effect of Work Discipline on employee performance in the Office of Public Appraisal Services Herly, Ariawan and Partners
}

\author{
Eni Puji Astuti', Nur Amalah², \\ 1.2 Universitas Pamulang \\ E-mail: eni.puji13@gmail.com
}

(Received: December-2017; Reviewed: January-2018; Accepted: February-2018;

Avalaibel Online: February-2018; Published: March-2018)

This is an open access article distributed under the Creative Commons Attribution License CC-BY-NC-4.0 @2018 by author (https://creativecommons.org/licenses/by-nc/4.0/)

\begin{abstract}
A company is required to have a disciplined view and attitude to increase employee productivity, work discipline is the most important human resource management function and is closely related to the management of resources for a company. The purpose of this study was to determine the work discipline at the Public Appraisal Service Office Herly Ariawan and Partners, to determine the performance of employees at the Public Appraisal Service Office Herly Ariawan and Partners, to determine the work discipline on employee performance at the Public Appraisal Service Office Herly Ariawan and Partners. The research method used is quantitative associative. The data was obtained by distributing questionnaires using a saturated sample to 30 employees at the Public Appraisal Services Office Herly Ariawan and Partners. Analysis of the data used is a simple linear regression equation, simple correlation, coefficient of determination, and significance test. The population is 30 respondents with a sample of 30 respondents. There is a positive influence, between Work Discipline on Employee Performance at the Office of Public Appraisal Services Herly Ariawan and Partners based on hypothesis testing using t test that $t_{\text {count }}>t_{t a b l e}$ or 2,053>1,701 then show significant results. Or in other words, $\mathrm{H}_{0}$ is rejected and $\mathrm{H}_{\mathrm{a}}$ is accepted. So it can be concluded that there is a significant influence between Work Discipline on Employee Performance at the Office of Public Appraisal Services Herly Ariawan and Partners.
\end{abstract}

Keywords: Work Discipline; performance; employee

\section{INTRODUCTION}

Companies are generally established with the aim to obtain maximum benefit. Human resource management is very important in achieving company goals (Akib \& Saleh, 2015; Awaliah, Amirullah, \& Saleh, 2015; Nasrullah, Rumingan, Nasaruddin, \& Niswaty, 2017; Norani, Amirullah, \& Darwis, 2015; Saleh, 2014). The issue of human resources is still the center of attention for a company to survive in the era of globalization accompanied by increasingly fierce competition. In a company, the potential of Human Resources (HR) needs to be managed as well as possible. The key to a company's success is not only on the benefits of 
assistance and the availability of funds, but the human factor is the most important (Garavan, 2007; Kammeyer-Mueller, 2015). Humans can be said as the main resources that are able to manage, analyze, and control the problems that exist in the company. In addition, humans have diverse desires, thoughts, feelings, statuses, and backgrounds that are brought into the company to achieve the company's goals. A company is required to have a disciplined view and attitude to improve employee productivity, work discipline is the most important human resource management function and is closely related to the management of resources for a company (Saleh, 2014; Wairooy, 2017).

Basically every employee realizes that work discipline is the key to success that must be applied and must be carried out by each individual because with good work discipline will provide smoothness in the process of carrying out work and will also achieve maximum work results within the company (Sunarsi, 2016). Through discipline will reflect strength, because usually, someone who succeeds in his work is those who have high discipline (Juhana \& Haryati, 2013; Saini, 2011; Schrift, 2013). Companies to maintain discipline for employees need special sanctions for violators of established rules. Sanctions can be in the form of reprimands, warnings or other things that aim to correct employee mistakes against violations committed by employees against established regulations so that this warning can make employees actually comply with the rules and discipline at work.

According to (Singodimendjo, 2011), discipline is an attitude of willingness and willingness to obey and obey the norms of regulations that apply around it. Employees who have a high level of discipline will obey all applicable regulations and will work with enthusiasm and diligence even if the leadership does not supervise directly (Nimpuno, 2015; Reza, 2010). But in its implementation at the Public Appraisal Service Office Herly, Ariawan and Partners still have not optimally assumed responsibility for the work provided, so there are still unsatisfied clients. Discipline in carrying out duties and responsibilities at work is very important and will impact on the company's performance and goals in the future. The conditions that are being experienced by employees have decreased employee performance, such as the delay of employees coming to work at predetermined office hours and frequent employees who do not enter. The increase in absenteeism of absent employees is also one of the factors in the decrease in work discipline, as shown in Table 1 below

Table 1.

Employee Attendance Data

\begin{tabular}{lcccccccc}
\hline No. & $\begin{array}{c}\text { Number of } \\
\text { employees }\end{array}$ & Year & $\begin{array}{c}\text { Amount } \\
\text { Working } \\
\text { days }\end{array}$ & $\begin{array}{l}\text { Total } \\
\text { Presence }\end{array}$ & $\begin{array}{c}\text { Number of } \\
\text { Attendanc } \\
\text { e }\end{array}$ & $\begin{array}{c}\text { Number of } \\
\text { Absences }\end{array}$ & $\begin{array}{c}\text { Attendance } \\
(\%)\end{array}$ & Absence (\%) \\
\hline 1. & 30 & 2014 & 122 & 3660 & 3400 & 260 & $29 \%$ & $71 \%$ \\
2. & 30 & 2015 & 122 & 3660 & 3510 & 150 & $60 \%$ & $40 \%$ \\
3. & 30 & 2016 & 122 & 3660 & 3380 & 280 & $24 \%$ & $76 \%$ \\
\hline
\end{tabular}

Source: HRD Office of Public Appraisal Services Herly, Ariawan and Partners

Based on table 1, it can be seen that the level of attendance of employees is not optimal, it can be seen from the data in the table that changes every year, namely in 2014 the percentage of attendance decreased by $29 \%$ and in 2015 showed an increase in absenteeism again increased to $60 \%$ and in 2016 again showed a significant decline to $24 \%$. With the decrease in attendance of employees can result in the completion of company tasks are not resolved properly. So it can be concluded that the work discipline at the Office of Public Appraisal Services Herly, Ariawan and Partners is still low and will have an impact on employee performance in completing their 
work. With the above problems, the achievement in completing corporate tasks is not resolved properly. So it can be concluded that the work discipline at the Office of Public Appraisal Services Herly, Ariawan and Partners is still low and will have an impact on employee performance in completing their work.

Kinerja merupakan hasil dan keluaran yang dihasilkan oleh perusahaan sesuai dengan perannya dalam perusahaan dalam suatu periode tertentu. Kinerja karyawan yang baik adalah salah satu faktor yang sangat penting bagi perusahaan untuk meningkatkan produktivitas (Hameed, Abdul, 2011; Shahzadi, Javed, Pirzada, Nasreen, \& Khanam, 2014). Performance is an indicator in determining how businesses to achieve high levels of productivity in a company. The company makes efforts to improve the performance of its employees.

Employee performance affects the number of jobs produced by employees is still not optimal, the low sense of responsibility is the main factor. There are still many employees who still do not work according to the provisions of the quality of work that has been applied in the company. Employees often procrastinate as a result of the length of the work process that is always not on time and will hamper work on other parts of employee performance. Many employees are still often late and absent from work affect the reduction in working hours which causes the performance of employees in the company to decline. The ability to work together on work that should make it easier to complete work, but many are still unable to work with other colleagues.

The condition of employee performance data at the Public Appraisal Services Office Herly, Ariawan and Partners, as seen from the results of the performance appraisal data from 20142016. It can be seen that the performance of employees in the Office of Public Appraisal Services Herly, Ariawan and Jakarta Central Partners in the last 3 years experienced a decline from 2014-2016 in all aspects from 79\% to 68\%. From the results of employee performance data it can be concluded that the performance of employees in the Public Appraisal Service Office Herly, Ariawan and Jakarta Central Partners is not optimal.

\section{METHOD}

This research is descriptive quantitative, namely research that provides an overview or description of data carried out in terms of knowing the relationship between the independent variable $(\mathrm{X})$ is work discipline and the dependent variable $(\mathrm{Y})$ is employee performance. According to (Sugiyono, 2016) the descriptive method is a method used to analyze data by describing or describing data that has been collected. As for this study, the population was employees of the Public Appraisal Services Office Herly, Ariawan, and Partners, totaling 30 employees. For research that wants to make generalizations with little or little error rates. So the sample in this study was 30 respondents. Data analysis used in this study is the validity and reliability test. Validity testing uses the Pearson product-moment correlation formula, with the provisions if the $r>$ table $r$, means the instrument is valid. Reliability testing in this study uses the value of Alpha Coanbach with the provisions if the Alpha Cronbach (count $r$ ) $>0.60$ means the instrument is reliable. Data analysis techniques include the classic assumption test and multiple regression analysis. The classic assumption test consists of a normality test, a multicollinearity test, a heteroscedasticity test, an autocorrelation test. In this study, a regression test was used to determine the relationship between the independent variables and the dependent variable whether it had a positive or negative effect. To find out how much the contribution or contribution of work discipline (X) to employee performance $(\mathrm{Y})$ can be calculated a coefficient called the coefficient of determination. The results are expressed as a percentage (\%). 


\section{RESULT AND DISCUSSION}

The purpose of this study was to determine the effect of work discipline on employee performance in the Office of Public Appraisal Services Herly, Ariawan and Partners

\section{Validity Test and Reliability Test}

Validity is a measure that shows the validity or validity of an instrument. So testing that validity refers to the extent to which an instrument in carrying out functions. The instrument is said to be valid if the instrument can be used to measure what is being measured. The reliability of the measuring instrument is the determination or constancy of the tool in measuring what it is measuring. That is, whenever the measuring instrument is used it will give the same measurement results. A test is said to be steady if the current measurement results show similarity of results at different times of the same respondent.

Table 2

Correlations

\begin{tabular}{|c|c|c|c|c|c|c|c|c|c|c|c|c|}
\hline & & $\begin{array}{c}\text { VAR } \\
01 \\
\end{array}$ & $\begin{array}{c}\text { VAR } \\
02 \\
\end{array}$ & $\begin{array}{c}\text { VAR } \\
03 \\
\end{array}$ & $\begin{array}{c}\text { VAR } \\
04 \\
\end{array}$ & $\begin{array}{c}\text { VAR } \\
05 \\
\end{array}$ & $\begin{array}{c}\text { VAR } \\
06 \\
\end{array}$ & $\begin{array}{c}\text { VAR } \\
07 \\
\end{array}$ & $\begin{array}{l}\text { VAR } \\
08 \\
\end{array}$ & $\begin{array}{c}\text { VAR } \\
09 \\
\end{array}$ & $\begin{array}{c}\text { VAR } \\
10 \\
\end{array}$ & $\begin{array}{l}\text { Discip } \\
\text { line }\end{array}$ \\
\hline \multirow[t]{3}{*}{$\begin{array}{l}\text { VAR } \\
01\end{array}$} & $\begin{array}{l}\text { Pearson } \\
\text { Correlation }\end{array}$ & 1 &,- 053 & ,270 & ,142 & ,359 & ,123 & $.408^{*}$ & ,027 & ,053 & ,299 & $.434^{*}$ \\
\hline & $\begin{array}{l}\text { Sig. } \\
\text { tailed })\end{array}$ & & ,781 & , 150 & ,454 & ,052 &, 516 & ,025 & ,886 & ,781 & ,109 & ,017 \\
\hline & $\mathrm{N}$ & 30 & 30 & 30 & 30 & 30 & 30 & 30 & 30 & 30 & 30 & 30 \\
\hline \multirow[t]{3}{*}{$\begin{array}{l}\text { VAR } \\
02\end{array}$} & $\begin{array}{l}\text { Pearson } \\
\text { Correlation }\end{array}$ &,- 053 & 1 & $.367^{*}$ & ,296 & $.381^{*}$ & ,111 & ,108 & ,268 & ,331 &,- 182 & $.520^{* *}$ \\
\hline & $\begin{array}{l}\text { Sig. } \\
\text { tailed })\end{array}$ & ,781 & & ,046 & ,112 & ,038 & ,558 & ,569 & , 153 & ,074 & ,335 & ,003 \\
\hline & $\mathrm{N}$ & 30 & 30 & 30 & 30 & 30 & 30 & 30 & 30 & 30 & 30 & 30 \\
\hline \multirow[t]{3}{*}{$\begin{array}{l}\text { VAR } \\
03\end{array}$} & $\begin{array}{l}\text { Pearson } \\
\text { Correlation }\end{array}$ & ,270 & $.367^{*}$ & 1 & ,342 & ,349 & ,008 & ,216 & , 101 & ,277 & $.413^{*}$ & $.595^{* *}$ \\
\hline & $\begin{array}{l}\text { Sig. } \\
\text { tailed) }\end{array}$ & , 150 & ,046 & & ,064 & ,059 & ,965 & ,252 & ,595 & , 138 & ,023 & ,001 \\
\hline & $\mathrm{N}$ & 30 & 30 & 30 & 30 & 30 & 30 & 30 & 30 & 30 & 30 & 30 \\
\hline \multirow[t]{3}{*}{$\begin{array}{l}\text { VAR } \\
04\end{array}$} & $\begin{array}{l}\text { Pearson } \\
\text { Correlation }\end{array}$ & ,142 & ,296 & ,342 & 1 & $.568^{* *}$ & ,213 & ,118 & ,014 & , 189 & ,243 & $.645^{* *}$ \\
\hline & $\begin{array}{l}\text { Sig. } \\
\text { tailed })\end{array}$ & ,454 & ,112 & ,064 & & ,001 & ,259 & ,534 & ,942 & ,318 & ,196 & ,000 \\
\hline & $\mathrm{N}$ & 30 & 30 & 30 & 30 & 30 & 30 & 30 & 30 & 30 & 30 & 30 \\
\hline \multirow[t]{3}{*}{$\begin{array}{l}\text { VAR } \\
05\end{array}$} & $\begin{array}{l}\text { Pearson } \\
\text { Correlation }\end{array}$ & ,359 & $.381^{*}$ & ,349 & $.568^{* *}$ & 1 & $.419^{*}$ & ,283 & ,089 & ,241 & ,145 & $.762^{* * *}$ \\
\hline & $\begin{array}{l}\text { Sig. } \\
\text { tailed })\end{array}$ & ,052 & ,038 & ,059 & ,001 & & ,021 & , 130 & ,639 & ,200 & ,444 & ,000 \\
\hline & $\mathrm{N}$ & 30 & 30 & 30 & 30 & 30 & 30 & 30 & 30 & 30 & 30 & 30 \\
\hline \multirow[t]{3}{*}{$\begin{array}{l}\text { VAR } \\
06\end{array}$} & $\begin{array}{l}\text { Pearson } \\
\text { Correlation }\end{array}$ & ,123 & ,111 & ,008 & ,213 & $.419^{*}$ & 1 & , 136 & ,064 &,- 052 & ,125 & $.437^{*}$ \\
\hline & $\begin{array}{l}\text { Sig. } \\
\text { tailed })\end{array}$ & ,516 & ,558 & ,965 & ,259 & ,021 & & ,472 & ,737 & ,784 & ,510 & ,016 \\
\hline & $\mathrm{N}$ & 30 & 30 & 30 & 30 & 30 & 30 & 30 & 30 & 30 & 30 & 30 \\
\hline \multirow[t]{2}{*}{$\begin{array}{l}\text { VAR } \\
07\end{array}$} & $\begin{array}{l}\text { Pearson } \\
\text { Correlation }\end{array}$ & $.408^{*}$ & , 108 & ,216 & ,118 & ,283 & ,136 & 1 &,- 008 & ,031 & ,252 & $.444^{*}$ \\
\hline & $\begin{array}{l}\text { Sig. } \\
\text { tailed })\end{array}$ & 025 & ,569 & ,252 &, 534 & ,130 & ,472 & & ,967 & ,871 & ,179 & ,014 \\
\hline
\end{tabular}




\begin{tabular}{|c|c|c|c|c|c|c|c|c|c|c|c|c|}
\hline & $\mathrm{N}$ & 30 & 30 & 30 & 30 & 30 & 30 & 30 & 30 & 30 & 30 & 30 \\
\hline \multirow[t]{3}{*}{$\begin{array}{l}\text { VAR } \\
08\end{array}$} & $\begin{array}{l}\text { Pearson } \\
\text { Correlation }\end{array}$ & ,027 & ,268 & ,101 &, 014 & ,089 & ,064 &,- 008 & 1 & $.449^{*}$ & , 179 & $.402^{*}$ \\
\hline & $\begin{array}{l}\text { Sig. } \\
\text { tailed })\end{array}$ & ,886 &, 153 & ,595 & ,942 & ,639 & ,737 & ,967 & & ,013 & ,343 & ,028 \\
\hline & $\mathrm{N}$ & 30 & 30 & 30 & 30 & 30 & 30 & 30 & 30 & 30 & 30 & 30 \\
\hline \multirow[t]{3}{*}{$\begin{array}{l}\text { VAR } \\
09\end{array}$} & $\begin{array}{l}\text { Pearson } \\
\text { Correlation }\end{array}$ & ,053 & ,331 & 277, & 189, & ,241 &,- 052 & ,031 & $.449^{*}$ & 1 & $.373^{*}$ & $.540^{* *}$ \\
\hline & $\begin{array}{l}\text { Sig. } \\
\text { tailed })\end{array}$ & ,781 & ,074 & ,138 & ,318 & ,200 & ,784 &, 871 &, 013 & & ,043 & ,002 \\
\hline & $\mathrm{N}$ & 30 & 30 & 30 & 30 & 30 & 30 & 30 & 30 & 30 & 30 & 30 \\
\hline \multirow[t]{3}{*}{$\begin{array}{l}\text { VAR } \\
10\end{array}$} & $\begin{array}{l}\text { Pearson } \\
\text { Correlation }\end{array}$ & 299 &,- 182 & .413* & 243 & 145, & 125, & 252 & ,179 & $.373^{*}$ & 1 & $.496^{* *}$ \\
\hline & $\begin{array}{l}\text { Sig. } \\
\text { tailed })\end{array}$ & ,109 & ,335 & ,023 & , 196 & ,444, & ,510 & ,179 & ,343 & ,043 & & ,005 \\
\hline & $\mathrm{N}$ & 30 & 30 & 30 & 30 & 30 & 30 & 30 & 30 & 30 & 30 & 30 \\
\hline \multirow[t]{3}{*}{$\begin{array}{l}\text { Disci } \\
\text { pline }\end{array}$} & $\begin{array}{l}\text { Pearson } \\
\text { Correlation }\end{array}$ & $.434^{*}$ & $.520^{* *}$ & $.595^{* *}$ & $.645^{* * *}$ & $.762^{* *}$ & $.437^{*}$ & $.444^{*}$ & $.402^{*}$ & $.540^{* *}$ & $.496^{* *}$ & 1 \\
\hline & $\begin{array}{l}\text { Sig. } \\
\text { tailed })\end{array}$ &, 017 & ,003 & ,001 & ,000 & ,000 &, 016 &, 014 &, 028 & ,002 & ,005 & \\
\hline & $\mathrm{N}$ & 30 & 30 & 30 & 30 & 30 & 30 & 30 & 30 & 30 & 30 & 30 \\
\hline
\end{tabular}

*. Correlation is significant at the 0.05 level (2-tailed).

**. Correlation is significant at the 0.01 level (2-tailed).

Based on the above SPSS output it can be seen that the statement item number 1 is $r>r$ table or $0.434>0.361$. This means that item 1 statement number work discipline variable $(\mathrm{X})$ is declared Valid. And it can be seen that the overall value of $r$ count has a value greater than $r$ table. It can be concluded that the 10 items are valid because $r$ count $>r$ table with a significance level of $5 \%$ for $\mathrm{n}=30$ is 0.361 .

Table 3.

Reliability Statistics

\begin{tabular}{|l|l|}
\hline $\begin{array}{l}\text { Cronbach's } \\
\text { Alpha }\end{array}$ & N of Items \\
\hline .716 & 10 \\
\hline
\end{tabular}

Based on the reliability test results above, it is known that the Cronbach alpha number is 0.716 where the figure is greater than the Cronbach alpha minimum value of 0.6 , therefore it can be concluded that the research instrument used to measure the discipline variable can be said to be reliable or reliable.

\section{Correlation Test and Dettermination Coefficient}

Table 4.

Model Summary

\begin{tabular}{|l|r|r|l|l|l|}
\hline Model & \multicolumn{1}{|l|}{ R } & R Square & $\begin{array}{l}\text { Adjusted } \\
\text { Square }\end{array}$ & $\begin{array}{l}\text { Std. Error of } \\
\text { the Estimate }\end{array}$ \\
\hline 1 & $.362^{\mathrm{a}}$ & .131 & .100 & 3.520 \\
\hline
\end{tabular}

a. Predictors: (Constant), Discipline 
Based on the table above it can be concluded the correlation (R) or the relationship between work discipline and employee performance of 0.362 is Weak. (Sugiyono, 2016) and explained the magnitude of the percentage of the effect of discipline on performance which can be seen from the coefficient of determination (R Square) of 0.131 which shows that the effect of discipline on employee performance is $13.1 \%$ while the rest is influenced by other variables.

\section{Simple Linear Regression Test}

Table 5.

Coefficients $^{\mathrm{a}}$

\begin{tabular}{|c|c|c|c|c|c|c|}
\hline \multirow{2}{*}{\multicolumn{2}{|c|}{ Model }} & \multicolumn{2}{|c|}{ Unstandardized Coefficients } & \multirow{2}{*}{$\begin{array}{l}\text { Standardized } \\
\text { Coefficients } \\
\text { Beta } \\
\end{array}$} & \multirow[b]{2}{*}{$\mathrm{T}$} & \multirow[b]{2}{*}{ Sig. } \\
\hline & & $\mathrm{B}$ & Std. Error & & & \\
\hline \multirow[t]{2}{*}{1} & (Constant) & 20.198 & 8.985 & & 2.248 & .033 \\
\hline & Disiplin & .441 & .215 & .362 & 2.053 & .049 \\
\hline
\end{tabular}

a. Dependent Variable: Employee Performance

Based on calculations obtained by the equation in the form of $\mathrm{Y}=20,198+0,441 \mathrm{X}$. The test results with statistics show the linear regression equation. This means the equation can be used to estimate the value of Employee Performance if Discipline is known. From the equation it can be seen that the coefficient $b$ is positive, this shows that changes in Employee Performance will increase if Discipline increases, conversely the value of Employee Performance will decrease if the Discipline value decreases.

From the table above it can be seen that the $t$-count $=2,053$ with a significance value of $0.049<0.05$. So Ha is accepted and Ho is rejected, which means that there is a significant influence between discipline on employee performance at the Office of Public Appraisal Services Herly, Ariawan, and Partners.

\section{CONCLUSION}

The discipline found at the Public Appraisal Service Office Herly, Ariawan, and Partners for their employees received good responses. Employee performance at the Public Appraisal Services Office Herly, Ariawan and Partners are still in the good category. There is a positive influence between discipline and employee performance at the Office of Public Appraisal Services Herly, Ariawan and Partners. It can also be seen the influence of work discipline on employee performance in the amount of $13.1 \%$ and the rest in the amount of $86.9 \%$ is influenced by other factors. And the results of the measurement of significance, tcount $>$ ttable or 2.053> 1.701 then $\mathrm{Ha}$ is accepted and Ho is rejected which means that the higher employee discipline, the higher employee performance is generated and vice versa, when employee discipline is low then the level of employee performance produced is also low

\section{REFERENCES}

Akib, H., \& Saleh, S. (2015). Pengaruh Kepala Sekolah Sebagai Supervisor Terhadap Kinerja Guru Di Smk Negeri 7 Makassar. Jurnal Office, 1(2), 141-147. 
Awaliah, N., Amirullah, A. H., \& Saleh, S. (2015). Kinerja Pegawai Negeri Sipil pada Kantor Kementerian Agama Kota Makassar. Jurnal Office, 1(1), 13-17.

Garavan, T. N. (2007). A Strategic Perspective on Human Resource Development. Advances in Developing Human Resources. https://doi.org/10.1177/1523422306294492

Hameed, Abdul, A. W. (2011). Employee Development and Its Affect on Employee Performance A Conceptual Framework. International Journal of Business and Social Sciences. https://doi.org/10.1080/09585192.2011.637072

Juhana, D., \& Haryati. (2013). Pengaruh Motivasi, Disiplin Dan Lingkungan Kerja Terhadap Kinerja Pegawai Pada Dinas Kesehatan Kota Cimahi. Jurnal Ekonomi, Bisnis \& Entrepreneurship.

Kammeyer-Mueller, J. D. (2015). Human Resource Management Practices. In The Encyclopedia of Adulthood and Aging. https://doi.org/10.1002/9781118521373.wbeaa223

Nasrullah, M., Rumingan, M., Nasaruddin, N., \& Niswaty, R. (2017). Pengaruh Pengambilan Keputusan Kepala Sekolah terhadap Kinerja Guru di SMK Negeri 1 Makassar. Jurnal Ad'ministrare: Jurnal Pemikiran Ilmiah dan Pendidikan Administrasi Perkantoran, 4(2), 103-110.

Nimpuno, G. A. (2015). Pengaruh Displin Kerja Dan Gaya Kepemimpinan Terhadap Kinerja Karyawan UD. Pustaka Pelajar Yogyakarta.

Norani, M., Amirullah, A. H., \& Darwis, M. (2015). Efektivitas Kinerja Pegawai pada Kantor Kementerian Agama Kota Makassar. Jurnal Office, 1(1), 1-7.

Reza, R. A. (2010). Pengaruh Gaya Kepemimpinan, Motivasi dan Disiplin Kerja Terhadap Kinerja Karyawan PT Sinar Santosa Perkasa Banjarnegara. Pengaruh Gaya Kepimpinan, Motivasi Dan Disiplin Kerja Terhadap Kinerja Karyawan Pt Sinar Santosa Perkasa Banjarnegara.

Saini, D. S. (2011). Book Review: Key Concepts in Human Resource Management. Vision: The Journal of Business Perspective. https://doi.org/10.1177/097226291101500111

Saleh, S. (2014). Penegakan Disiplin (Suatu Upaya Peningkatan Kinerja Pegawai). Jurnal Ad'ministrare, 1(1), 8-19.

Schrift, A. D. (2013). Discipline and Punish. In A Companion to Foucault. https://doi.org/10.1002/9781118324905.ch5

Shahzadi, I., Javed, A., Pirzada, S. S., Nasreen, S., \& Khanam, F. (2014). Impact of Employee Motivation on Employee Performance. European Journal of Business and ManagementOnline).

Singodimendjo. (2011). Manajemen Sumber Daya Manusia. Jakarta: Bumi Aksara.

Sugiyono. (2016). Metode Penelitian dan Pengembangan (Research and Development/R\&D). In Bandung: Alfabeta. https://doi.org/10.1016/j.drudis.2010.11.005

Sunarsi, D (2016). Pengaruh Minat, Motivasi Dan Kecerdasan Kognitif Terhadap Prestasi Belajar (Studi Kasus Pada Mahasiswa Program Studi S-1 Manajemen. Fakultas Ekonomi. Universitas Pamulang. Thn. Akademik 2015-2016). In Proceedings (Vol. 1, No. 1).

Wairooy, A. (2017). Pengaruh Disiplin Kerja dan Kompensasi Terhadap Kinerja Karyawan pada PT. Pertamina (Persero), Tbk. Pemasaran Region VII Makassar. Jurnal 
46 Pinisi Discretion Review

Volume 1, Issue 2, March, 2018 Page. 39- 46

Ad'ministrare: Jurnal Pemikiran Ilmiah dan Pendidikan Administrasi Perkantoran, 4(1), $15-24$. 